\title{
O MÚLTIPLO COMO ARGUMENTO POÉTICO EM PROCESSOS CRIATIVOS
}

\author{
THE MULTIPLE AS A POETIC ARGUMENT \\ IN CREATIVE PROCESSES
}

\section{Marcillene Ladeira UNIPAC}

\section{Resumo}

O texto circunstancia o recorte de uma fundamentação teórico-prática na qual a palavra-imagem múltiplo é instaurada como um dos argumentos poéticos empregado nas obras autorais da artista-pesquisadora Marcillene Ladeira. Como metodologia, utiliza-se o mergulho histórico, tendo, neste transcurso, a gravura como ponto de partida - pois a esta linguagem, conforme consenso à falta de pesquisadores, originalmente reserva tal conceituação -, bem como a investidura sobre estratégias contemporâneas de criação, enfatizando, especialmente, a imagem figurativa, artistas e obras. Sustenta-se que o múltiplo entendido enquanto possibilidade de reprodução "numa espécie de linha de montagem" - permitiu estabelecer diálogos profícuos de pensamento. Em uma leitura de aproximação com a Pop, mas em envergadura diferenciada, as obras em discurso transitam do imaginário do consumo para o pós-consumo, cuja poética se sustenta por três conceitos operacionais: "liquidez", "respeito a natureza" e "transitoriedade" enquanto seres viventes. As relações dialógicas estabelecidas no lugar da exposição também são evidenciadas como estratégia pessoal de produção e singularidade deste fazer, sobre a égide da interfase: múltiplolugar-poética.

\section{Palavras-chave:}

Gravura; Múltiplo; Poéticas Contemporâneas.

\section{INTRODUÇÃO}

O que é múltiplo? Quais são as suas relações históricas no contexto artístico? $\mathrm{Na}$ contemporaneidade, como foi efetivado sua legitimidade enquanto argumento poético? De que modo utilizo este estatuto no meu fazer? Eis o
Abstract

The text provides a clip of a theoretical-practical foundation in which the multiple word-image has established as one of the poetic arguments used in the authorial works of the artist-researcher Marcillene Ladeira. By methodology, the historical diving is used, to take this course, the engrave as a starting point - because this language, according to a consensus with abundance of researchers, originally reserves this concept -, as well as the investiture on contemporary strategies of creation, emphasizing especially the figurative image, artists and works. It has maintained the multiple - understood as the possibility of reproduction "in an assembly line type" - allowed establishing a fruitful dialogue of thinking. In a reading of rapprochement with Pop, but in a different wingspan, the discourse works move from the imaginary of consumption to post-consumption, whose poetics is supported by three key operational concepts: "liquidity", "respect for nature" and "transience" as living beings. The dialogical relations established in the place of the exhibition are also evidenced like a personal production strategy and singularity of this doing, under the aegis of the interphase: multiple-place-poetics.

Keywords:

Engraving; Multiple; Contemporary Poetics.

propósito deste estudo - ao artista-pesquisador, para além das técnicas plásticas que utiliza, está a essência dos conceitos que operaciona.

Ao seguir esta via de interesse e desbravamento, o presente artigo progride com a referida estrutura: elementos "pré" e "pós-textuais", "introdução" 
(como aqui vem se subscrevendo), "desenvolvimento" e "considerações finais". O desenvolvimento, em seu bojo, está constituído de três grandes tópicos: a) a gravura e o múltiplo; b) o múltiplo como conceituação contemporânea; c) o múltiplo nas relações dialógicas no lugar da exposição.

O primeiro título (A gravura e o múltiplo) inicia-se com a explicação quanto a terminologia da palavra "múltiplo", passando-se a um mergulho histórico através dos tempos e, tendo, neste transcurso, a gravura como ponto de partida daquele - linguagem que, conforme consenso à farta de pesquisadores, originalmente reserva tal conceituação. Entendese que fazer correspondências da produção autoral, numa consciência histórica aos fatos precedentes, de certo é uma maneira de fundamentar remodelações ao sistema teórico; e mais do que isto, é captar insights promissores quanto a adoção da plasticidade da(s) obra(s) em percurso. Trata-se, então, de adentrar em um espaço, parafraseando Rosane Preciosa - professora da disciplina "Tópicos em Artes, Cultura e Linguagens VIII", referente ao Curso de Doutorado do Programa de Pós-Graduação em Artes Cultura e Linguagem, do Instituto de Artes e Design, da Universidade Federal de Juiz de Fora, MG (PPGACL/IAD/UFJF), à qual este texto está vinculado - de "polinização de ideias". (PRECIOSA, 2019, p. 02).

Em outras palavras, não um posto "coagulado", aprisionado em modelos pré-fabricados de nossa trajetória escolástica. Ou, absorvendo-me ainda mais de recursos linguísticos, de modo a exprimir um duplo sentido das palavras - "função emotiva" - assenta-se: um lugar de ideias reprodutivas - múltiplos sem alma. Já expressara Adriana Varejão em entrevista realizada a ela em 2010, em virtude de sua exposição "Entre Carnes e Mares": "tenho uma visão otimista da História como algo em constante transformação e que o passado precisa estar se alimentando do presente e não ao contrário". A renomada artista brasileira ainda continua: "comentar sobre a tradição não significa estar estagnado nela. É preciso abrir sempre as janelas, movimentar o ar". Por fim, conclui: o(s) artista(s) deve(m) ser(em) "como minhocas, que arejam a linguagem" (VAREJÃO apud TRIGO, 2010).

Tão logo, ainda para esta incursão nas bases históricas, mas adentrando-me em um olhar mais conclusiva sobre a intenção da mesma, arremato meu pensamento: remexo, misturo, peneiro até encontrar um novo rearranjo; e, como à maneira de Varejão, procuro "ser uma agente da História, criando identidades, influências e versões próprias" (VAREJÃO apud TRIGO, 2010). Ou em outras palavras, cabe a mim (artista-pesquisadora), a partir de certas orientações, as quais por elas decido, mover-me e apropriar-me das formas (sejam plásticas ou textuais) que "me olharam, no momento que as vejo" (Didi-Huberman, 1998) (eis minha postura). E, então, ordenar tais fenômenos e deixar circular as ideias, para que neste compasso arejado e assentado, o processo de pesquisa, em Artes Visuais, se efetive.

Neste transladar, no segundo título (O múltiplo como conceituação contemporânea), tendo em mente a ideia de meu fazer autoral, desbravo caminhos entre criações que dialogam com o que venho produzindo: Pop Art, década de 1950/60 e a cultura de consumo, a qual possibilitou a reprodução do objeto de arte "numa espécie de linha de montagem", bem como "estabeleceu diálogo entre ordens culturais populares e a grande cultura". (BAUDRILLARD, 1997, p.186 apud NOCERA, 2011, p. 56).

Presencia-se que a referida produção autoral, que pregoa não o consumo, mas o pós-consumo e seu impacto na sociedade contemporânea, resultando em três reflexões específicas que destas questões emanam: "liquidez dos tempos", "respeito à natureza" e "transitoriedade da existência" - passa-se ao trio de conceitos operacionais que perfazem o modus operandi de meu fazer. O mesmo, foi iniciado em pesquisa de pós-graduação Stricto Sensu, grau mestrado, sendo defendida com o título "Campo das Vertentes: uma coleta pictórica", realizada sob orientação da Professora Doutora Maria Virgínia Gordilho Martins (Viga Gordilho) ${ }^{1}$, no Programa de Pós-Graduação em Artes Visuais, Escola de Belas Artes, Universidade Federal da Bahia (PPGAV/ EBA/UFBA), linha "Processos Experimentais na Arte Contemporânea", com desdobramentos outros, a partir de então (2014/2015).

Para este processo, longe de querer ombrearme e sim (talvez) na intenção de quebrar a extensão do texto, ou, ainda, situar o lugar que falo - criação artística: acabo por apresentar imagens de proposições plásticas de outros 
artistas, mas, também, tomei a liberdade de incluir produções autorais - enfim, fotocópias de trabalhos multiplicados.

$\mathrm{Na}$ intencionalidade deste caminhar poético, de certo, também poder-se-á parafrasear a francesa de Nivole Malenfant, a qual pronúncia que, para além da renovação "material e simbólica", o artista-pesquisador deverá preocupar-se com as "relações dialógicas no lugar da exposição" (MALENFANT 2002, p. 19 apud TAVORA, 2013, p. 125). É desta colocação que nasce o terceiro título (O múltiplo nas relações dialógicas no lugar da exposição), e sobre ele perfaço novas pontuações na interfase: múltiplo-lugar-poética. E deste compasso, então, adentro o momento atual vivido, e, traço colocações que presenciam visibilidade e uma atualização renovada do meu fazer.

\section{A GRAVURA E O MÚLTIPLO}

Múltiplo, em terminologia de dicionário (do latim multip/us), se define como aquilo que não é simples; composto, diverso, plural; relativo a uma quantidade maior que um número determinado. No contexto característico da arte, significa a obra plástica produzida em quantidade para ser coloca ao alcance do público, estando em Walter Benjamin (Berlim/Alemanha, 1892-1940) como: "destruição da aura" ou "perda de sua unicidade"2.

Como se sobrechegou no contexto de expressão plástica? Historicamente, as diferentes linguagens artísticas carregam ambivalências inelutáveis no processo de maturidade como instrumento (enfim) de criação plástica contemporânea. Neste contexto atual, alguns criadores da arte evocam procedimentos e materiais próprios à faina de execução, conservando seu grau de pureza na íntegra; outros, já se aventuram em procedimentos expansivos inovadores, se beneficiando, a exemplo, das mais altas tecnologias ou desenvolvimentos científicos outros, instituindo uma forte tendência a amálgamas. Seja como for, na fundamentação deste desbravar quanto as origens históricas do múltiplo, em sua essência, nos dirá Walter Benjamin (2020, p.54): "a obra de arte foi, em princípio, sempre reprodutível" ("produtividade técnica"), isto é, "sempre foi possível, a pessoas, imitar aquilo feito por pessoas". Essa imitação era praticada por "estudantes, como treino na arte; por mestres, para a disseminação de suas obras", mas também (a de se destacar) o interesse ao lucro financeiro. E nestes trâmites, completa o autor, afirmando: "a reprodução técnica da obra de arte [...] se realiza na história de modo intermitente, em impulsos largamente espaçados, mas com intensidade crescente", até eclodir-se (então) na atualidade. (Cf. BENJAMIN, 2020, p. 94). Em outras palavras, parafraseando Rui Miguel Pinto Vasquez (2000, p. 55) "a arte multiplicada constitui uma resposta [...] em resultado da continua e progressiva evolução social, econômica e cultural das sociedades industrializadas".

Tomando como exemplo a arte holandesa, durante o período conhecido como "o Século de Ouro" (das representações), ver-se-á que os artistas se beneficiaram de aparelhos óticos como auxiliares neste processo, isto é, por ser uma província recém liberta da Espanha, a Holanda se tornara o refúgio dos maiores intelectuais da época, com grande desenvolvimento científico. Uma de suas atividades econômicas de destaque foi, propriamente, a venda de lentes e espelhos utilizada, tanto para a visualização de imagens macro e micro, quanto no uso das projeções. Assim, artistas, naturalistas e astrônomos passaram a fazer largo uso das câmaras escuras (e claras em sua evolução), dos microscópios e dos telescópios como instrumentos ordinários de trabalho. O impacto na arte foi imediato: as figuras desenhadas proliferaramse nos livros, nos mapas, nos quadros, nas porcelanas. Tudo era motivo de representação através da imagem e, certamente, estava bem mais fácil de ser executada. Por essa via, passa-se a entender a grande presença de artistas figurativos em terras germânicas: "estima-se que, de uma população que, no século XVII, chegava a cinco milhões de pessoas, dois milhões eram pintores ou sabiam alguma técnica de pintura" - como assim explica Marlon César de Alcântara (2011). 0 referido pesquisador, nos revela, também, a forte comercialização destes aparatos tecnológicos entre regiões, resultando em grande abundância na Europa.

Neste caminhar de revoluções tecnológicas, conforme colocação de Maria Luísa Távora (2013, p. 123), evidencia-se, de certo, o interesse dos artistas pela execução de diferentes meios artísticos, configurando-se, por exemplo, a expressão "pintores-gravadores" - que passou a ser usada no século XIX. Não obstante, a gravura estampada fora o ponto de partida do então uso 
do múltiplo (citação específica, que não a palavra escrita, embora saiba-se da importância que representa também neste contexto). Assim, sobre a gravura, Távora nos fornece um dado quantidade de sua reprodutividade (século XIX): "dez mim por ano, 30 por dia". As peças confeccionadas neste novo momento histórico iam desde produtos ligados às artes gráficas (e com ela a palavra escrita), quanto à gravura como meio de expressão (fortemente no uso da imagem, mas não apenas ela). Nomes como "Renoir, Corot, Manet, Cézanne, entre outros, passaram a disputar a atenção deste novo mercado de arte". (Cf. TÁvORA, 2013, p.123). Ou como explica Benjamim (2020, p.54): a litografia está para a técnica usada no início do século XIX, a qual a "reprodutividade atinge um patamar fundamentalmente novo" [...] não apenas massivamente (como até então), mas também em variações diariamente renovadas."

"Com a fotografia, a mão foi, pela primeira vez, aliviada das mais importantes obrigações artísticas no processo de reprodução figurativa, as quais recairiam a partir daí exclusivamente sobe o olho". $E$, então, "o processo de produção figurativa foi acelerado de modo tão intenso que agora ele podia acompanhar o ritmo da fala." (Cf. BENJAMIN, 2020, p. 55).

Ao desbravar um pouco mais, voltando até as origens da gravura, tendo em vista sua relação com o múltiplo, Maria do Carmo Veneroso (2010, p. 87) afirma que está para uma das formas mais antigas de representação plástica, antecedendo até mesmo a existência humana na terra. Sua presença configura-se na própria natureza, através dos fósseis, cujas plantas ou animais deixaram suas marcas em determinadas superfícies de formações rochosas ou camadas sedimentares, que por pressão (pegadas/rastros) ou calcinação (reação química de decomposição dos corpos ou parte desses) produziram naturalmente a ideia de impressão. Antônio Costella (2006, p. 20, grifo do autor) explica: "impressão é a ação de um corpo sólido sobre o outro. Im pressão, pois, é a pressão em algo, sobre algo", cuja "raiz [...] está no verbo latino premere, isto é, apertar".

Em um viés similar deste processo, cita-se a marca que resulta de um corpo sobre o lençol estendido na cama, a qual configura-se, a valer, como um registro gráfico "bidimensional"; ou como nos angaria Costella (2006, p. 20): “o pé calcado na areia da praia. [...] 0 pé é o molde, a fôrma, a matriz [...]. O mesmo pé, pressionado outras vezes, resultará em outras tantas cópias [...]"; como o seu corpo deitando-se sobre diferentes camas. Mais recentemente, o referido processo natural (na especificidade de uso de recurso vegetal) foi atribuído o nome de "foligrafia" - do latim folium, folha. É uma gravura, pois a mesma matriz pode produzir várias e sucessivas cópias - múltiplos, portanto (COSTELLA, 2006, p. 65).

Na sequência, de algum modo, e mais uma vez à luz de Costella (2014, p.16): "o homem aprendeu a desenhar e, nas paredes das cavernas, reproduziu figuras de animais e cenas da vida primitiva", incorporando este ato às habilidades humanas. "Talvez com base nesta experiência, [...] a partir de então, lançou os fundamentos daquilo que viria a ser a escrita". De modo a exemplificar, neste processo, estariam os traços "do caçador, anotando com riscos [...] a quantidade de presas abatidas, ou mais tarde, já no Neolítico [ldade da Pedra], os do lavrador, marcando a sucessão das luas, para escolher a época mais apropriada ao plantio, ou esboçando a mensuração das colheitas". (Cf. COSTELLA, 2014, p.16). Quiçá, o homem já não teria iniciado o caráter da reprodução, nestas primeiras formas de registro?

Herbert Baldus (1899-1970), etnógrafo nascido na Alemanha e que viveu no Brasil por certo período, ao realizar uma catalogação de carimbos de povos primitivos - no caso, os indígenas - nos revela uma grande variedade deste instrumento. 0 mesmo relato também está presente entre os antigos "artistas viajantes"3. Ao analisar estes instrumentos, vemos que funcionaram como verdadeiras matrizes de impressão, na realização de desenhos tribais, sendo utilizados com tintas naturais, como o "urucu" e pressionados sobre a pele nua, ou ainda no vestuário humano.

No estudo publicado por Erland Nordenskiöld (1918, p. 147 apud BALDUS, 1961/62, p. 07), sob o título: "carimbos da América do Sul", para o seu fabrico, o pesquisador menciona tanto uso de varetas e chapas de madeira, como o "barro cozido" - e, muitas vezes, até mesmo frutos em sua forma natural eram empregados, como o "babaçu" ou "talo de buriti". Também havia uma variação em seu formato de aplicação: maneira 


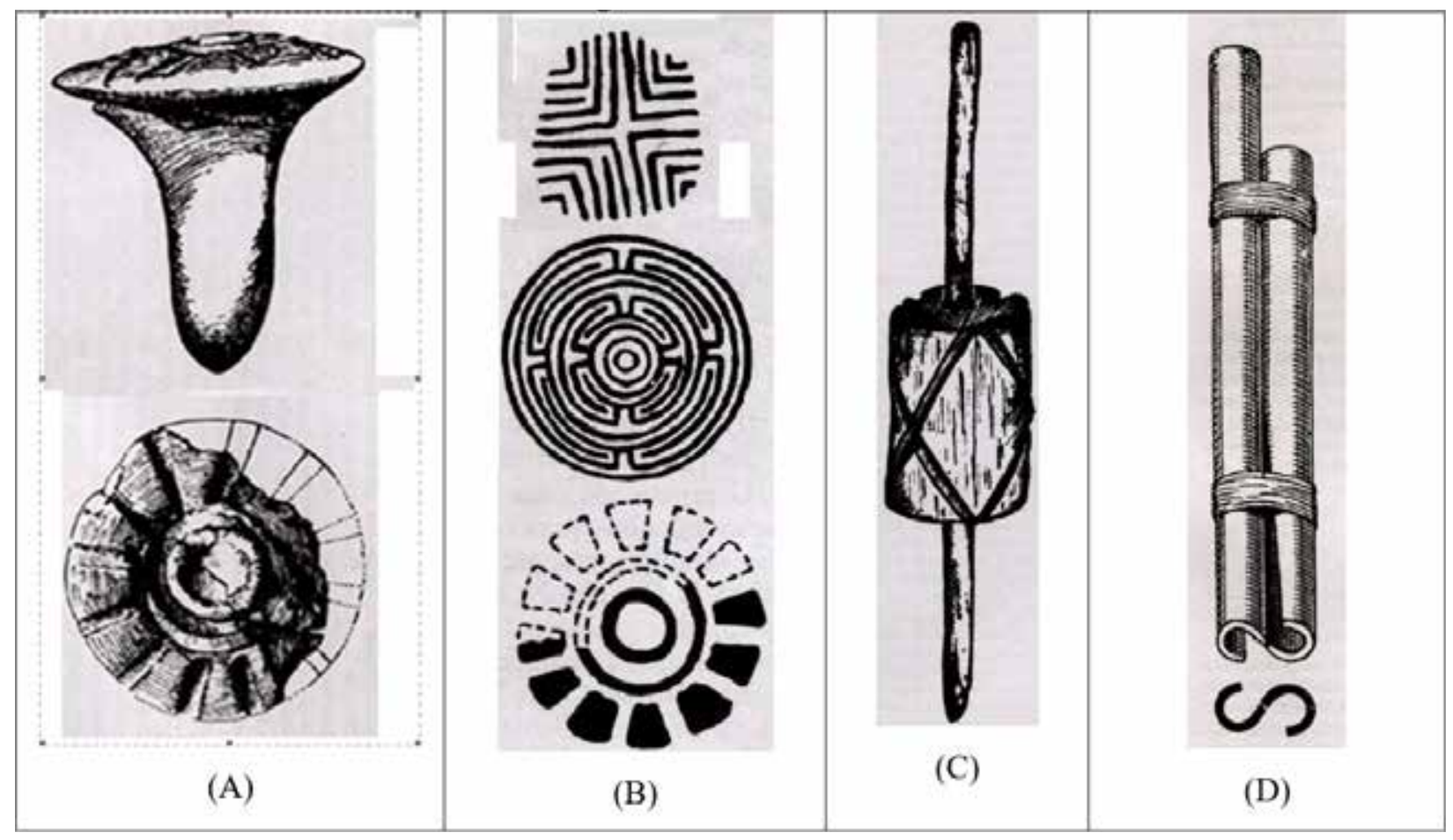

Figura 1 - Modelos de Carimbo. Fonte: BALDUS, Herbert, Coleção Nicolai, 1961/62, pp. 53; 53; 29; 35.

planária ou cilíndrica. Na imagem seguinte (Figura 1), apresenta-se algumas variações. $\operatorname{Em}(A)$ e (B) há modelos confeccionados em barro, seguindose dos desenhos estampados através deles; em (C) identifica-se carimbo cilíndrico de talo de buriti; em (D) carimbo plano de "taquara" / vareta e sua respectiva impressão.

Sobre o barro cozido (cerâmica), é de interesse assinalar que, conforme traz Rui M. P. Vasquez (2000, p. 09), passa-se a ser utilizado pelo homem desde o domínio do fogo, conquistado ainda no Paleolítico - primeira fase da Pré-História.

Ao atribuir continuidade, uma outra vertente do múltiplo que extrapola as duas dimensões, e talvez a própria definição de gravura, se é que os exemplos dados já não o fizeram, mas que, por extensão, também poderia estar contida nela como assim é firmado por Antônio Costella (2006, p. 8) - estaria a ramificação escultórica, a qual gera formas tridimensionais, como (a exemplo) no trabalho manual do ourives ou do chapeleiro. Processos estes definidos por impressão a seco, isto é, sem uso de tinta. Sobre este aspecto, de igual modo, há uma continua e progressiva evolução. Inicialmente, encontra-se na manufatura de variados artefatos, como os de defesa e utilização agrícola, datados da Idade dos Metais - última fase da Pré-História. Primeiro o homem, na ignorância da metalurgia, fez uso do "ouro, prata, chumbo e cobre", sendo trabalhados no estado sólido, como se de uma pedra tratasse. "Só quando descobriu que os metais se modificavam, [ao serem fundidos], é que nasceu a metalurgia"; isto é, os diferentes metais ao serem aquecidos até ao ponto de fusão, podem ser despejados em um recipiente que, após o arrefecimento, ganham a sua forma - como assim nos explica Rui M. P. Vasquez (2000, p. 9). O referido autor, ainda, afirma: foi deste processo físico-químico que nasceu a fundição ou moldagem. Ou, em outros termos, diz respeito aos primeiros passos técnicos, do homem, de modo a caminhar em prol da "produção em massa"; rompendo, enfim, com efeitos naturais e/ou mais rudimentares. Portanto, quanto "a primeira capacidade técnica para produzir objetos artísticos [tridimensionais] múltiplos ou de série, [data] da Idade do CobreBronze", ocorrida ainda na Pré-História (2( fase). (Cf. VASQUEZ, 2000, p. 9).

Na sequência, passamos a ver a replicação de peças maiores e mais detalhadas como as estátuas de figuração humana ou de deuses. Antony Mason (2009, p. 18) nos cita, a exemplo, a presença de fôrmas utilizadas pelos gregos, como 
no processo da "cera perdida", na qual "algumas cópias poderiam ser feitas com base em um único original", confeccionado primeiramente de argila.

Ao voltar aos processos bidimensionais da gravura, enquanto habilidade humana desenvolvida, evidencia-se, a xilogravura - uma variação de impressão que tem como matriz a madeira (do grego xilon). Embora não exista um consenso exato entre os pesquisadores, da mesma, sua introdução no Ocidente está para o aparecimento do papel, e, o fabrico em quantidade significativa, com forte acesso, teria ocorrido apenas no século XV (MARTINS FILHO, 1982, p.11). Momento este, no qual o múltiplo assiste, também, a outro fortalecimento; agora, quanto a reprodução da palavra escrita, através da imprensa por Johannes Gutenberg, 1430 - primeiro homem a utilizar os tipos móveis de metal.

Antes deste processo mecanizado, Renata Santos (2008, p. 25) observa que a impressão do texto, quanto junto a imagem, fora trabalhada em blocos únicos de madeira (placas inteiriças) e impressas sob pressão manual. Martins Filho (1982, p. 12) traz sua denominação: livros tabulares ou "incunábulos xilográficos". Mais de dois terços destas impressões teriam sido redigidas em latim (língua universal na época), sendo de carácter religioso.

$\mathrm{Na}$ habilidade quanto na feitura das imagens desenhadas, Antônio Costella (2006, p. 36) aponta o alemão Albrecht Dürer (1471-1528) como um dos nomes mais expressivos do período em curso (renascimento). Dürer (ele mesmo) não entalhava os blocos, realizava o desenho, passando-se as mãos dos artesãos que cuidava do entalhe e posterior impressão - era a divisão das funções, próprio da época.

Em passos recortantes, ver-se-á que da evolução mecânica, seguem-se à estampa em chapa de metal plana, passando-se à pedra (processo litográfico) criada, então, em fins do século XVIII, pelo alemão Aloysius Senefelder (1771-1834), com pleno uso no século XIX. Quando entra a fotografia.

No decorrer, a matriz de pedra da litografia é substituída por chapas finas de metal; convertendo-se, da impressão planária à rotação cilíndrica - nasce, assim, o sistema offset, de produtividade e automação bem maior.
Para além destes andamentos já citados, destacam-se outros mecanismos de reprodução: a) invenção do "Mimeógrafo", cujo lançamento data de 1880, com primeiro uso efetivo em 1887 (CAMPOS, 2009, p. 40). b) A impressão no modo "Xerox". A palavra xerografia vem do grego e significa "escrita a seco", trata-se de um processo que passou a ser comercializado a partir de 1960. c) Quanto as "impressoras", tiveram inúmeras evoluções, desde a "matricial" ao processo a "laser". Esta, surgida no mercado em 1977 - modelo IBM 3800. (COSTELLA, 2006, p. 66). d) A "Serigrafia" ou, do inglês, Silk screen, constitui-se de um processo cuja impressão está para a característica de permeação ${ }^{4}$. A primeira patente data de 1907, realizada por Samuel Simon, Inglaterra, com aplicação na estamparia industrial. (COSTELLA, 2006, p.114). e) A técnica da "Sublimação" refere-se à reprodução que se beneficia de uma impressora, cuja imagem resultante é submetida a ondas de calor. Isto faz com que a imagem previamente impressa, sentido espelho, se transfira do papel para o suporte de tecido. f) Para finalizar, ainda, cito os processos de gravura editados via computador. Conforme Costella (2006, p. 126), se desembocam no que se chama de "gravura eletrônica" ou "infogravura", cujo códigos substituem o meio tradicional por codificações de zeros e uns.

\section{O MÚLTIPLO COMO CONCEITUAÇÃO CONTEMPORÂNEA}

Discutidos percursos históricos precedentes quanto ao uso do múltiplo (relações do bi e do tridimensional), passar-se-á a tensionalidades do mesmo como conceito. // Empregar o múltiplo no meu fazer poético não foi uma decisão aleatória ou tomada de chofre. Segundo Luigi Pareyson (1993, p. 45), "a escolha de uma matéria se acha implícita no próprio definir-se de uma intenção formativa". Assim, os trabalhos realizados durante o mestrado foram determinantes, ou seja, as tendências do percurso de criação é que me conduziram ao seu uso. Tratou-se de uma união entre suas características, às minhas intencionalidades previamente delimitadas, e cujo aprofundamento se processa nos momentos de "campo" ou de "pausa" subsequentes, a exemplo desta escrita, conforme já reportado. 


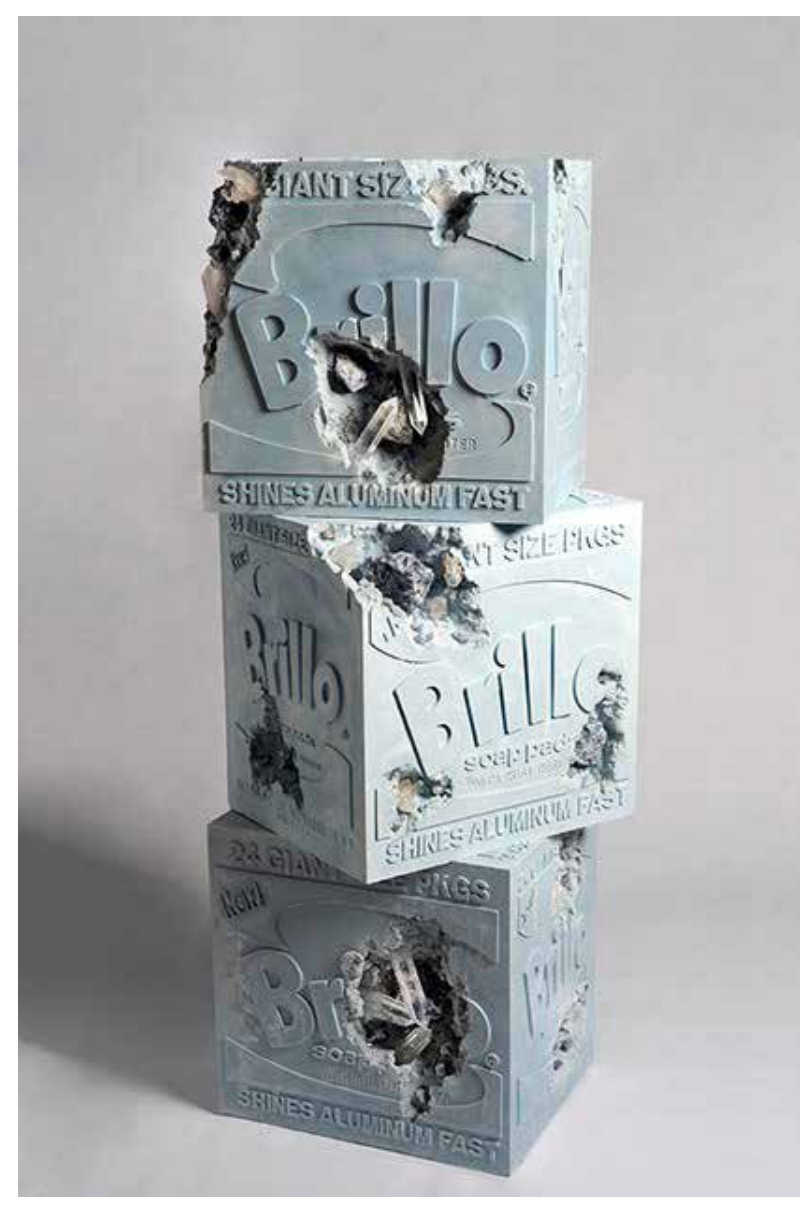

Figura 2 - Eroded Brillo Box, Daniel Arsham, dimensão $(130,5 \times 44,5 \times 44,5 \mathrm{~cm})$, originais de 2019.

Fonte: DASARTES, 2020.

Assim, neste compasso, a partir das novas reflexões oriundos entre a leitura de diferentes textos teóricos e falas abertas em sala de aula (ainda que de maneira presencial virtualizada, tendo em vista os acontecimentos do ano em curso), ideias vão sendo lançadas. Mais uma vez, faço referência aos escritos da Professora condutora da disciplina - Rosane Preciosa (2019, p.1, título), que afirma: é necessário "reparar nas coisas: de repente algo acontece e somos outro". De certo, para que isto se dê é preciso estabelecer conexões salutares; e, é claro, não deixar que elas se percam pelo caminho. Em outras palavras, é necessário atentar para "os sopros" "que nos empurram para as beiradas da compreensão" assim completo à luz ${ }^{5}$ de Hélio Oiticica (1986, p. 22) e Peter Pál Pelbart (2013, apud PRECIOSA, 2019, p. 02) amarrando parte de meu pensamento nas palavras deste texto. $E$ como na preocupação levantada por Preciosa (2019) em trecho subsequente: no desbravar da pesquisa, é também de significância, não deixar que "a voz daquele que pensa e escreve encontra[r]-se ausente" (p. 1).
No caminhar desta disciplina, se a poesia e, também, a música se tornaram fontes de inspiração à reflexão, é na melodia desta e na sincronização daquela que estabeleço, um pequeno paralelo. Isto é, a minha abertura ao múltiplo sucedeu-se à maneira do que se passa com o jazz - ritmo musical que se sustenta no próprio ato de sua execução. $E$ dando continuidade a este compasso, entra a pesquisa pessoal. Estaria para à novas fontes e/ou fontes atualizadas de pesquisa. À vista disso, e estando para as plasticidades das obras, a imagem que abriu este título (Figura 2) refere-se a uma produção na qual se identifica a presença do múltiplo. A "Eroded Brillo Box" ou "Caixa Brilho Corroída", é uma edição de 500 peças, foi realizada pelo artista norte-americano Daniel Arsham (1980), e incorpora a simbólica obra "Brilho Box" de Andy Warhol, 1964 e a cultura Pop. Arsham, acrescenta a ela uma compreensão de tempo. Este, é claramente evidenciado pelo desgaste do material calcinado; e cuja pronúncia do autor fora: "supostamente encontrado via escavação arqueológica" (DASARTES, 2020). A obra produzida primeiramente em 2019, com replicação em 2020, fora realizada em colaboração com o Andy Warhol Museum, é constituída de cristal de quartzo e outros materiais geológicos calcificados; possui peso de $7 \mathrm{~kg}$; inclui-se ao pacote "uma etiqueta holográfica da Arsham Editions", a qual verifica o seu número de edição e autenticidade. (DASARTES, 2020).

Como mais uma forma de rememoração ao período Pop, a imagem seguinte (Figura 3) apresenta a obra intitulada "Lata de sopa Campbell" (Campbell's Soup Cans), datada também de 1964, que além das repetições da mesma embalagem, distinguese, ainda, variações cromáticas. Estas foram pintadas em homenagem ao rótulo das trinta e duas variedades de sopas oferecidas pela empresa Campbell no mercado; um conjunto que atualmente é acervo permanente do MOMA (Museum of Modern Art), Nova Iorque/EUA (MASON, 2009, p. 120).

À maneira de Daniel Arsham e na incorporação simbólica da obra "Lata de sopa Campbell", também de Warhol, a imagem subsequente (Figura 4) expõe uma proposição artística desenvolvida por mim, no percurso de Mestrado, que hoje se encontra no acervo da galeria “Luiz Fernando Ladeiro, Arte Contemporânea", Salvador, BA. 

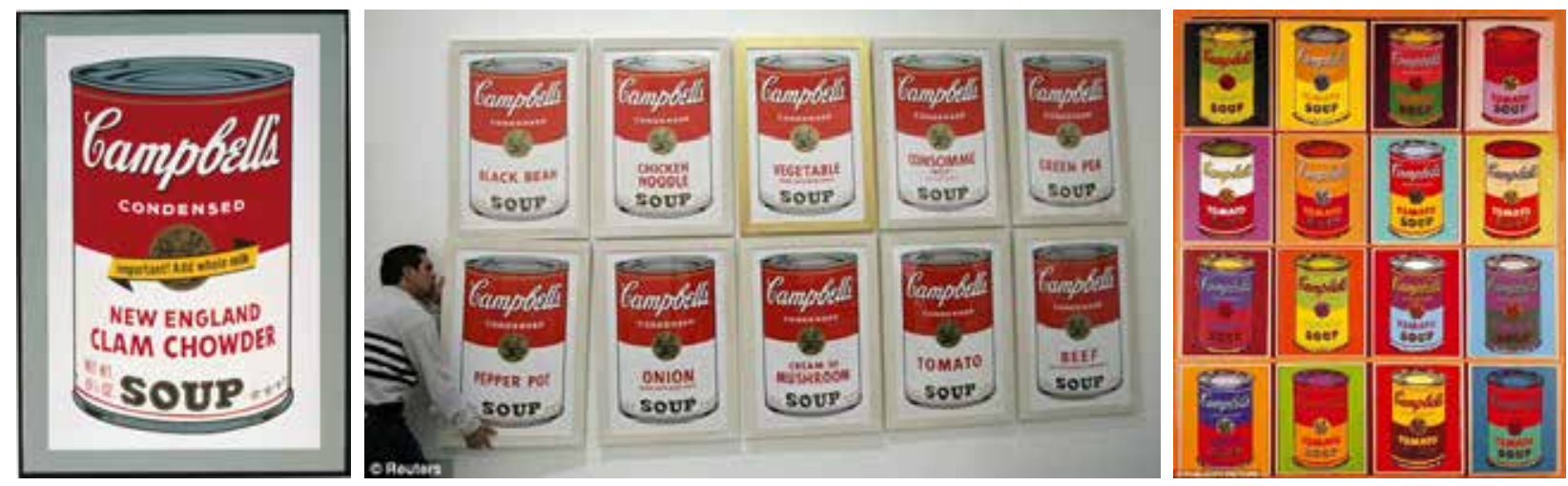

Figura 3 - Andy Warhol, 1964, Lata de sopa Campbell (Campbell's soup), repetições e variações cromáticas. Fonte: 〈http://www.dailymail.co.uk/ news/article-2195347/Andy-Warhol-Campbells-soup-launch>
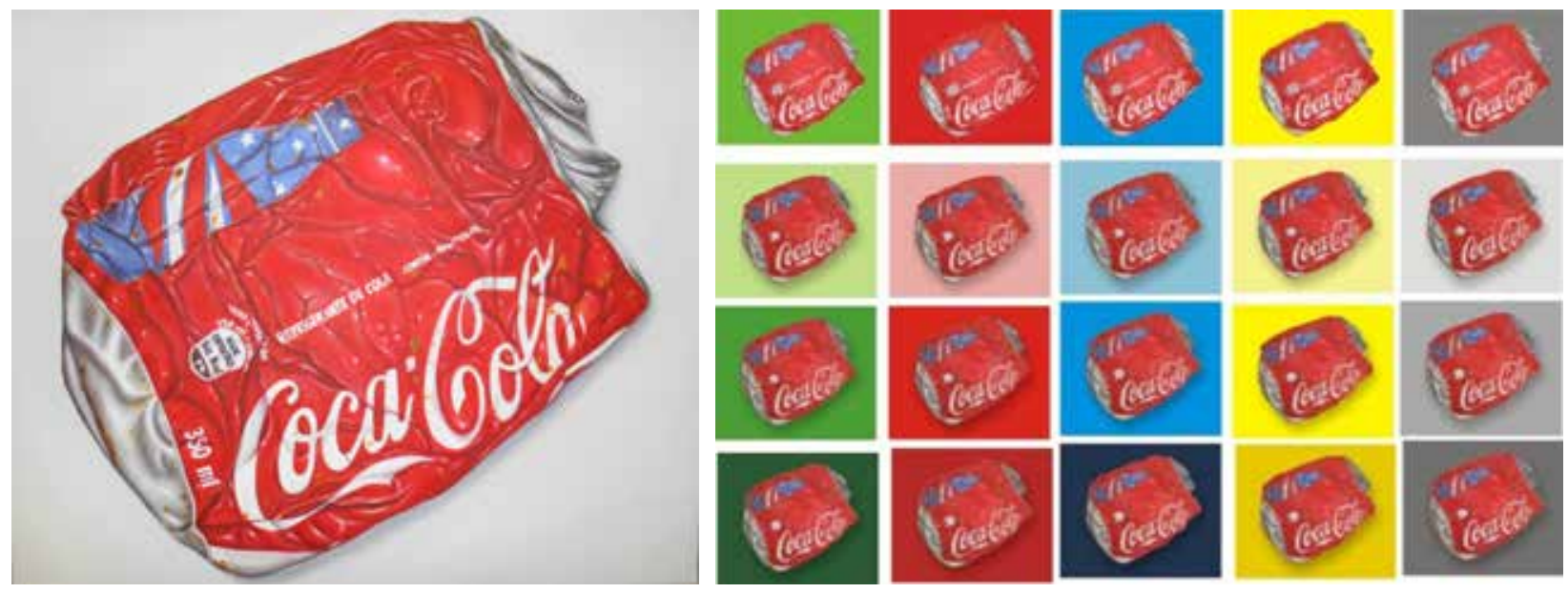

Figura 4 - Marca/Marco I, OST, $100 \times 120 \mathrm{~cm}$; repetições e variações cromáticas, 20(40x40cm); 2014/15. Fonte: produção pessoal da autora; acervo galeria: Luiz F. Landeiro Arte Contemporânea.

A obra é constituída de uma "matriz" realizada em pintura, técnica óleo sobre tela e, seus múltiplos, se tornaram visíveis pela técnica da impressão digital sobre tecido. Os mesmos, foram assinados e numerados de modo a evidenciar o serial. Diferindo da Pop, na minha obra, o produto de consumo (Coca-Cola) encontra-se em uma situação de descarte (lata vazia e amassada); o serial apresenta-se em variações cromáticas de fundo que perfazem uma leitura ao Código de Cores da Reciclagem ${ }^{6}$, sendo composto de dez cromas: verde, vermelho, azul, amarelo, cinza; branco, preto, laranja, roxo e marrom.

Aproximando-me de Warhol e Arsham, transformei objetos retirados das experiências cotidianas de consumo, em obras de arte, incorporando a compreensão deste "fazer", o tempo, que faz as pessoas meditarem quanto as transitudes $d a$ existência. Em outras palavras, diz-se da liquidez dos tempos. E como tal, pensar no respeito para com a natureza.

Vale observar que a aludida incursão, neste primeiro momento da segunda década do século $\mathrm{XXI}$, tendo em vista a pandemia do coronavírus (SARS-CoV2), e pela própria experimentação sobre a mesma, novas formas de pensar tem sido agregada. Quanto ao recorte na disciplina de doutorado, cita-se, como ponto de leitura realizada: "Monólogo do Vírus - eu vim parar a máquina, cujo freio de emergência vocês não estariam encontrando" (texto anônimo); "Aprendendo do Vírus", por Paul B. Preciado e "Do Tempo", por Ailton Krenak - de fato, os três textos tecem considerações devota a fragilidade à vida, que, certamente, no agora, abre-se 

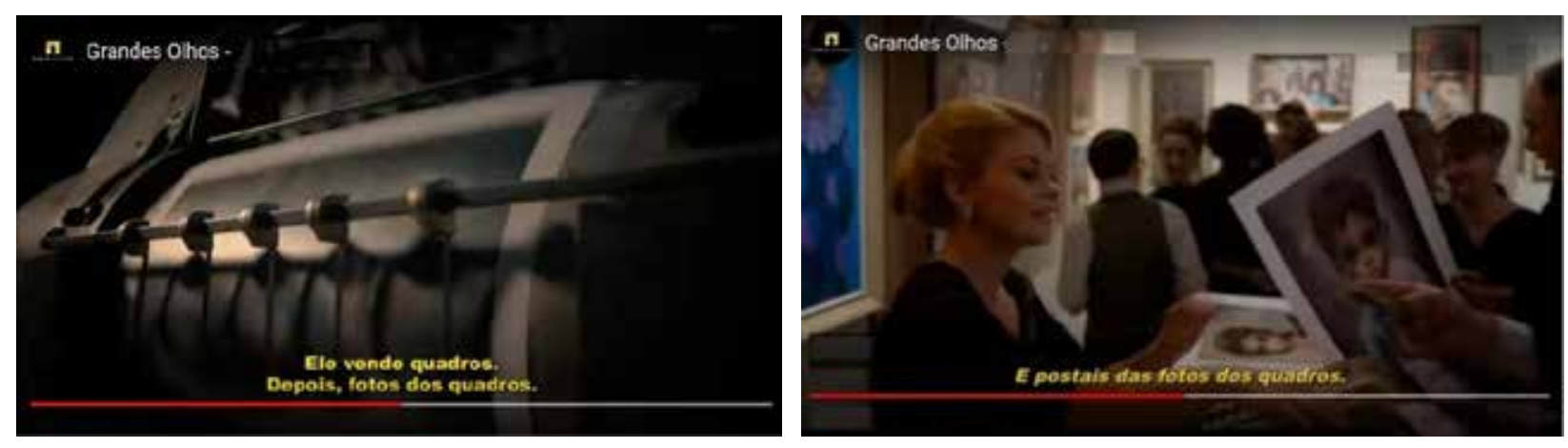

Figura 5 - Cenas do Filme "Grandes Olhos" Fonte: Drama/Romance, 1h46m, Direção: Tim Burton, 2014/2015 como um novo sinal de alerta e posicionamento humano frente as realidades vindouras. Ou como na voz de Paul B. Preciado:

vivemos em novas formas de consumo [...] que dominam a sociedade contemporânea. Essa mutação se dissemina e se amplia agora, em gestão da crise da COVID-19 - as nossas máquinas portáteis de telecomunicações são os nossos novos carcereiros, e nossos interiores domésticos se tornaram a prisão branda e ultraconectada do futuro. (PRECIADO, 2020).

Após citar Warhol (1928-1987), artista originário da publicidade, que empregou a técnica da serigrafia para se chegar a larga escala; em Margaret Keane $(1927)^{7}$, ambos americanos e artistas mais rentáveis dos anos de 1950/1960, temos uma pintura, realizada em técnica tradicional. Seu trabalho fora vendido, não apenas a obra em si (quadro), bem como inúmeras reproduções imagéticas. A sequência de imagens a seguir (Figura 5 ), foram retiradas do filme "Grandes Olhos", que narra a história real da pintora.

Estes dois caminhos que o múltiploperfaz, apontam continuidades possíveis. De qualquer modo, neste desembaraço, é efetivado como conceituação contemporânea, de anuência pela crítica de arte. Ou seja, se na abrangência histórica, a aceitação do múltiplo fora uma ambiguidade, parece solucionada no contemporâneo, em particular, pelos artistas gravadores.

Em meio ao translado de defesas teóricas, Arthur Danto (2013, p. 82) expressa: "toda e qualquer coisa estava agora à disposição dos artistas, e nada mais na arte podia ser invalidado pela crítica de que estivesse historicamente incorreto". Não mais pintura e escultura, e sim uma "co-fusão" de linguagens (performances, happenings, bodyart), bem como experiências ainda mais improváveis (a serigrafia, o xerox, o offset, o fax), passam a categoria artística. A serigrafia, no viés da produção de Warhol, por exemplo, há um caráter de expressão apoiada na ideia de se assemelhar a produtos comerciais, estando como em uma linha de montagem.

Maria Luisa Távora (2013, p. 125) expressa: "o reconhecimento da gravura original como obra de arte supõe a compreensão da multiplicidade e da pluralidade como modalidades de existência". É integrada ao campo da arte, sobretudo, no período Moderno, passando-se ao Contemporâneo - a partir, então, desta sua própria singularidade - que nasce a poética. Portanto, o múltiplo está entre suas características precípuas, ou seja, é conceito.

Na voz de Walmir Ayala, observamos a explicação subsequente, de modo a firmar a ideia do múltiplo como conceito:

A reprodução não é simplesmente um fenômeno de repetição, como sustenta ainda um pensamento que vai buscar suas razões na etimologia ou no hábito. Ela corresponde a um conjunto de operações numerosas e complexas que fazem dela uma produção. (AYALA, 1973 apud TAVORA, 2013, p. 125).

Há, também, de se ater que esta fala refere a uma mudança ocorrida ainda durante a gravura iniciada como expressão, isto é, no período moderno como anteriormente citado. Foi neste momento que passou a ser executada, em toda a sua fase: concepção, gravação e impressão da imagem, por um único artista, que assina suas tiragens e estados, em versão manuscrita (antes, conforme escrito no primeiro título, havia a divisão das funções). Neste viés que o 

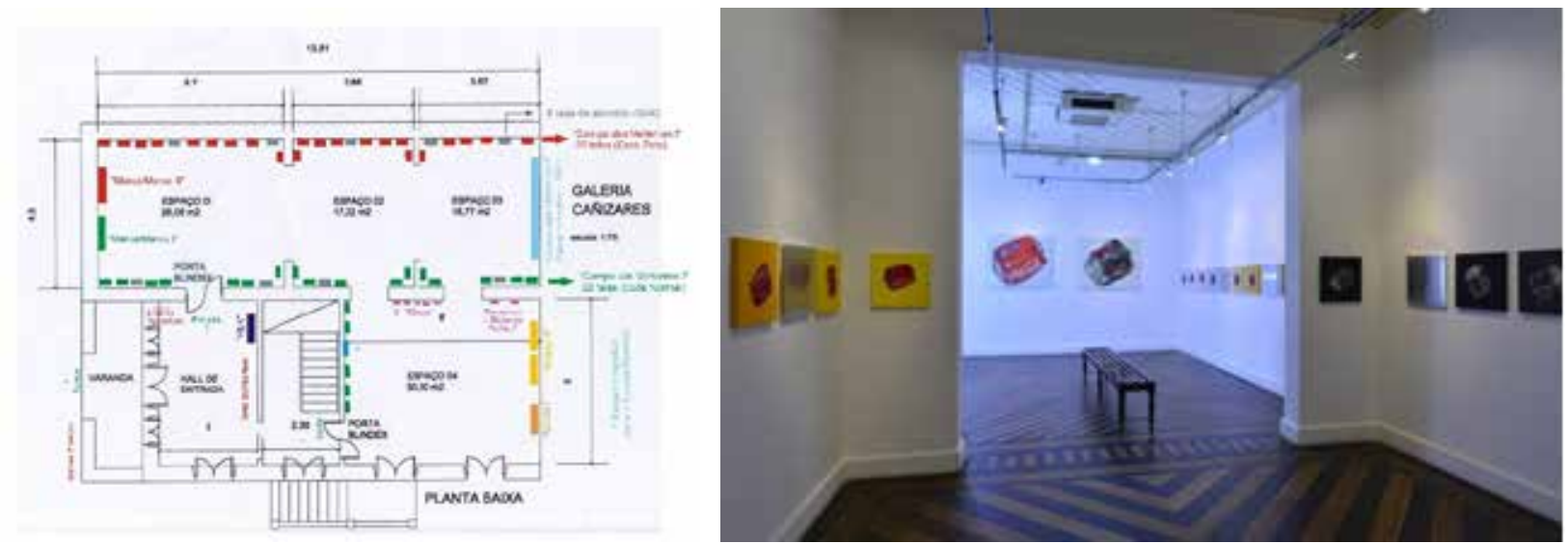

Figura 6 - "Projeto Expográfico", Galeria Cañizares, 03.2015; Vista Interna, sede na EBA/UFBA. Fonte: arquivo pessoal da autora, 2014/2015.

Fotografia: Péricles Mendes.

contemporâneo se abre e se lança a apropriações cada vez mais livres e audaciosas.

\section{O MULTIPLO NAS RELAÇÕES DIALÓGICAS DO LUGAR DA EXPOSIÇÃO}

Nivole Malenfant, autora de vários livros, em seu texto La singularité du multiple defende com propriedade as exigências da gravura em seu estágio contemporâneo. Entre as considerações que vem sendo circunstanciadas, destaco (neste momento) o fato de o artista, entre suas estratégias pessoais de produção (ou modos singulares de ver), atentar-se (também) para "as relações dialógicas [estabelecidas] no lugar da exposição". Ver-se-á esta afirmação na voz de Malenfant:

A singularidade deve de fato emergir mediante uma experimentação estética individual que saberá renovar não só sua presença material e simbólica, mas também suas relações dialógicas no lugar de exposição [...] (MALENFANT, 2002, p.19 apud TAVORA, 2013, p.125, grifo nosso).

Diante desta consideração, na imagem seguinte (Figura 6) apresento o Projeto Expográfico da mostra de final de curso de Mestrado, intitulada: "Campos das Vertentes: uma coleta pictórica", ao lado de uma fotografia da vista interna - ambiente expositivo: Galeria Cañizares, Escola de Belas Artes, UFBA, ano 2015, Salvador/BA.

Observar-se-á que na sequência do Projeto Expográfico há pontos em vermelho e em verde; estes estão respectivamente para os múltiplos ou as variações cromáticas de pinturas, que respeitaram suportes e materiais convencionais, tidas como referências ou "matrizes".
Segundo Marta Isabel G. Soares (2011, p. 09, grifo da autora), o étimo "matriz" chega ao português vindo do latim matrix, icis cujos principais significados estão para: fêmea, mãe, tronco, origem, útero, lugar onde alguma coisa se gera, cria ou forma. No contexto das "Artes", a referida autora (2009, p. 12) descreve que "matriz" está, para o "molde a partir do qual se produzem cópias ou exemplares". Em outras palavras, ao citar Maria Isabel Faria e Maria Pericão ${ }^{8}$, Soares complementa afirmando que "matriz" se refere a um "método de reprodução técnica de imagens ou objetos"; questão que, de igual modo, é confirmada por Georges DidiHuberman $1993^{9}$ (apud SOARES, 2011, p. 19) em seu "Formas de genealogia: a impressão como uma matriz".

Logo, poder-se-á considerar que este fazer, o qual envolve matriz e seus múltiplos - "os filhos" - (no meu ponto de expressão) e em um sentido contemporâneo de interpretação (ou alargamento), está para à noção de cadeia operativa que envolve não só toda uma gama de recursos técnicos inerentes "ao fazer" como todas as contingências específicas da atividade criativa - desde os materiais empregados, às técnicas, às condições específicas do lugar de exposição (como aqui vem se desbravando), e até mesmo, há de se considerar o local aonde se põem em prática os fazeres (se assim for necessário).

Ao me referir ao sentido de "alargado", destaco Antônio F. Costella (2006, p. 19), o referido autor afirma que na gravura tradicionalmente pensada a obra final está para os "múltiplos" da matriz e não 

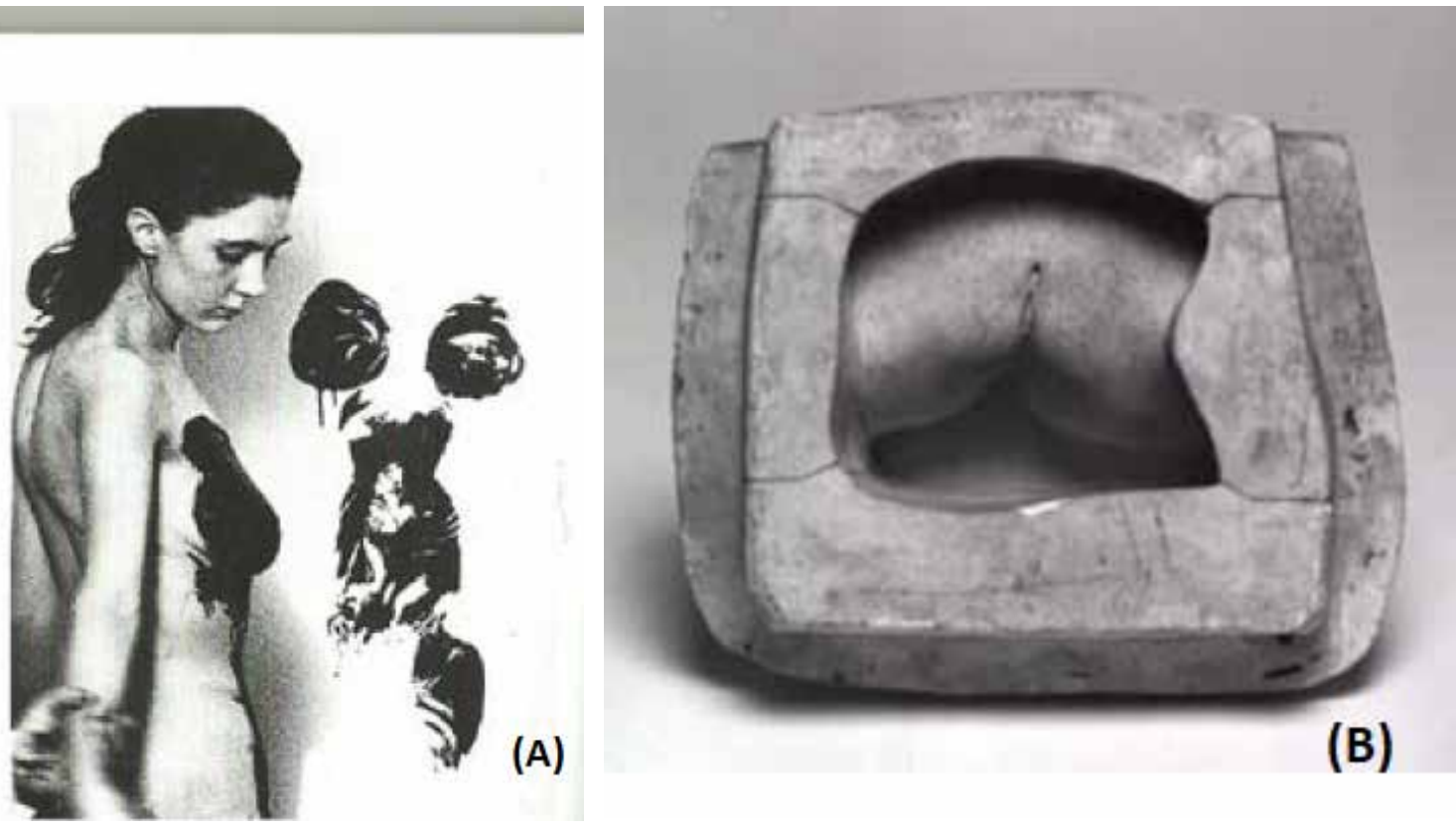

Figura 7 - (A) "Yves Klein, manifestação no atelier: a mulher-pincel, 1960.

(B) Marcel Duchamp, Molde/Matriz em gesso, constituída por 5 peças (negativo de Feuille de Vigne Femelle), Coleção MNAM, Paris/França.

Fonte: Marta Isabel G. Soares (2011, p.35)
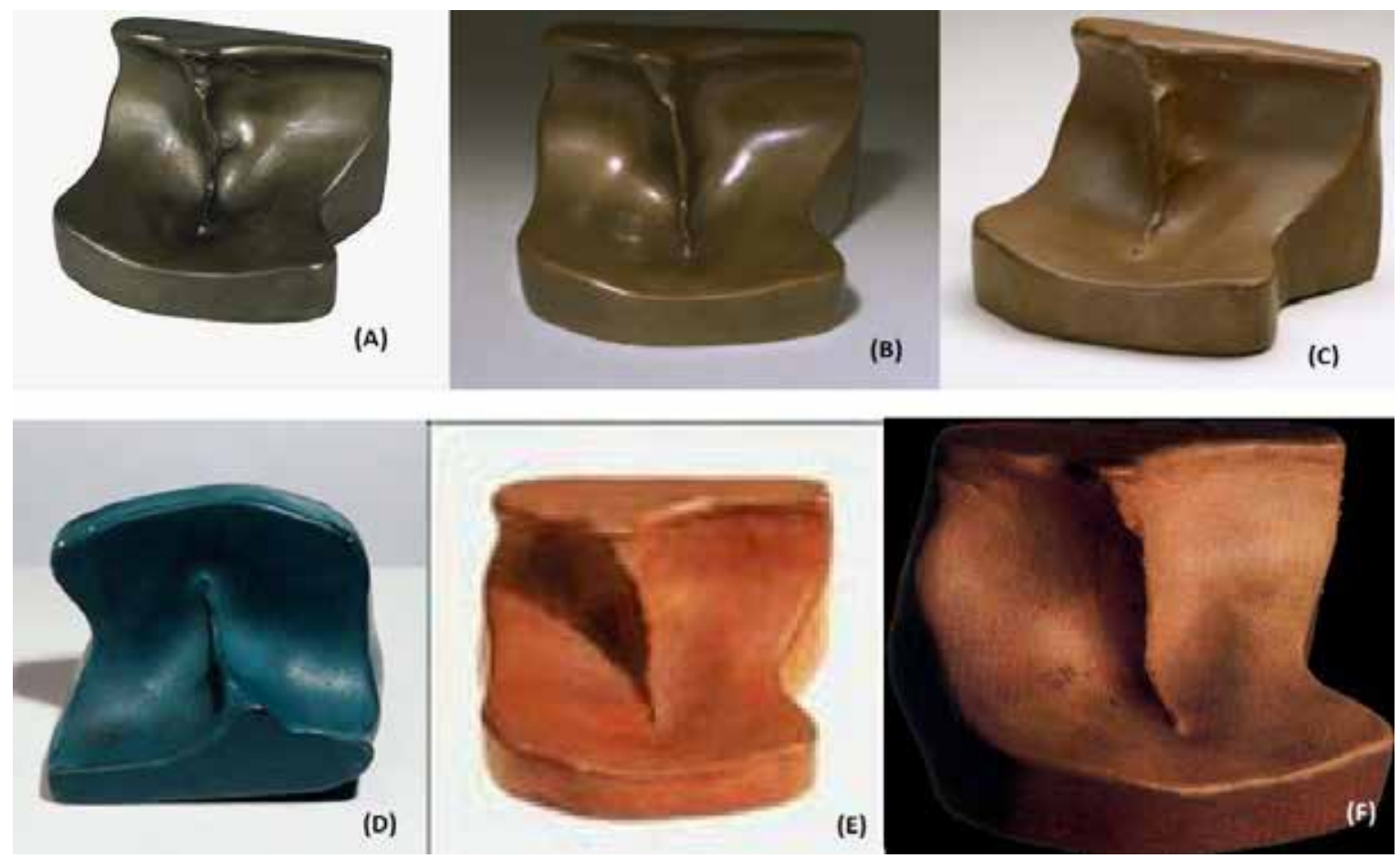

Figura 8 - Marcel Duchamp, múltiplos da obra "Feuille de Vigne Femelle" (Folha

Feminina de Videira). (A) 1950/1961, Bronze, 9 × 14 x 12,5 cm, National Galleries of Scotland, Escócia. (B) 1950/1961, Tate Gallery, Inglaterra. (C) 1950, Cobre galvanizado sobre gesso, 8,6 x 13,3 x 12,7 cm., Oferta de Jasper Johns ao MoMa, Museum of Modern Art, Nova lorque. (D) 1950, Gesso galvanizado, $9 \times 14 \times 12,5 \mathrm{~cm}$, MNAM, Paris. (E) 1950, Gesso galvanizado, The Israel Museum, Jerusalem. (F) 1950, Gesso galvanizado, 9 × 14 x 12,5 $\mathrm{cm}$, Colecção Particular, Paris. Fonte: Marta Isabel G. Soares (2011, p.35) 

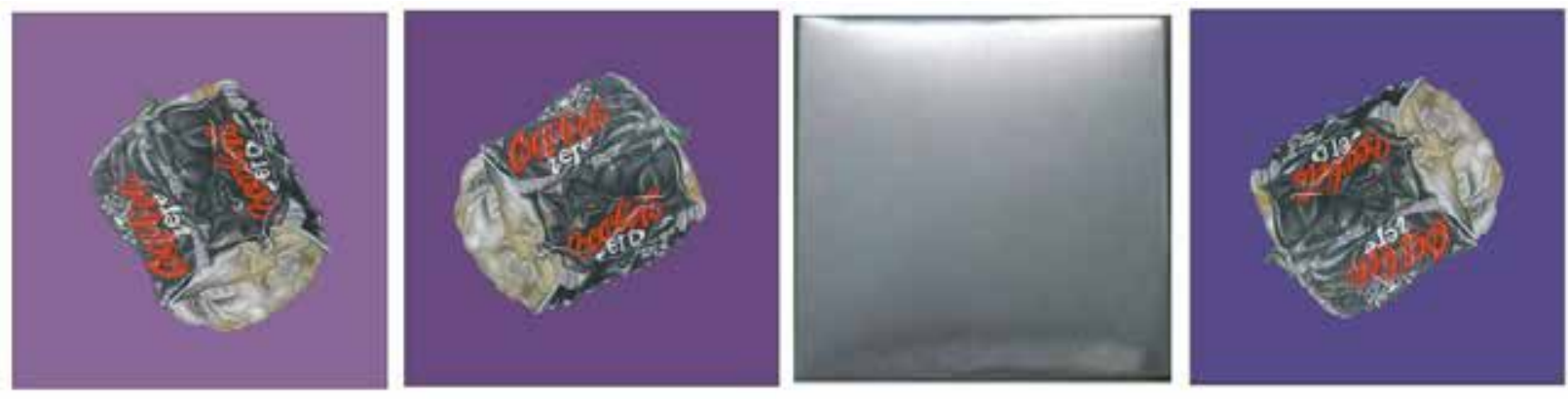

Figura 9 - Ambiente expositivo, exemplo da disposição dos múltiplos em rotação horária e o rompimento do ciclo; Obra "Marca/Marco II", dimensão: $40 \times 40 \mathrm{~cm}$ cada; impressão digital sobre tecido. Fonte: Produção da autora, acervo da galeria representante. Fotógrafo: Péricles Mendes

para ela própria. Observar-se-á que no período moderno já se identifica matrizes também sendo exibidas como obras, a exemplo de "A mulherpincel", de Yves Klein, 1960 (Figura 7 - A) e a proposição de Marcel Duchamp, "Feuille de Vigne Femelle" (Folha Feminina de Videira), de $1950 \mathrm{em}$ diante: molde/matriz em gesso (Figura 7 - B) e respectivos múltiplos (Figura 8 ).

Desta citação, presencia-se, portanto, que esta mesma característica ou relação entre matriz e múltiplo está presente em meu fazer: ambos são diálogos inerentes a poética visual colocados em evidência no local expositivo.

Também, neste processo, há de se considerar a disposição visual dos múltiplos. Foram organizados seguindo a escala tonal operacionalizada: Código da Reciclagem (conforme já explicitado), com variações cromáticas em cada matiz, e, mais do que isto, estão para uma linha de raciocínio cíclico (rotação horária de $360^{\circ}$ ) - diz-se da organização ecológica dos ecossistemas vivos, cuja quebra indica desequilíbrio. No caso de minha produção, a quebra do ciclo é sinalizada pela presença de uma tela de materialidade diversa, isto é, confeccionada em alumínio puro. Na imagem seguinte (Figura 9), apresenta-se isto.

Para além deste fator que nos remetem a intencionalidade da crise ambiental, atentase que a ideia de "ciclo" está, de igual modo, para um "processo metodológico de criação artística" instaurado no percurso deste fazer. Isto é, à luz de Fritjof Capra, em seu "A teia da vida: uma nova compreensão científica dos sistemas vivos" (1996) e Cecília Salles, no seu "Redes de Criação, Construção da obra de arte"
(2006), traço um modo de pensar e agir na arte, perante seis elementos comuns e necessários à manutenção desta grande "teia de produção". São eles: Redes, Ciclos, Parceria ou Aliança, Diversidade, Equilíbrio Dinâmico e Energia Solar. Ao indicar o significado de "Ciclo", este remete a fenômenos que se sucedem numa ordem continua deixando seus rastros para novas produções. No montante, têm-se o que chamo de Plasticidade do Pensamento em Criação (detalhes maiores podem ser vistos em outro texto, ${ }^{10}$ resultante desta mesma pesquisa, não sendo o foco no momento).

Em continuidade às produções e a efetivação dos múltiplos, cita-se uma segunda exposição ocorrida no Museu Regional de São João Del Rei, sob o título "Entre Mares", ano 2017, e desta, evidencia-se uma modelação composta de 24 unidades, sob o título "Engradado", executadas na linguagem da cerâmica, Figura 10. Nesta, somente os "filhos" foram expostos.

\section{CONSIDERAÇÕES FINAIS}

Seguindo o rastro do processo criativo vivido no Mestrado, através da Pesquisa "Campos das Vertentes: uma coleta Pictórica" e seus desdobramentos, o múltiplo foi posto como conceito contemporâneo operacionalizado - uma reflexão aqui construída, que buscou trazer a teoria para junto da obra pensada em processo, mas, sobretudo, a obra finalizada. E esta foi exemplificada com produções não apenas pessoais, mas também (como, próprio da pesquisa em poéticas visuais), de obras tidas como referência, entre o manancial existente. 

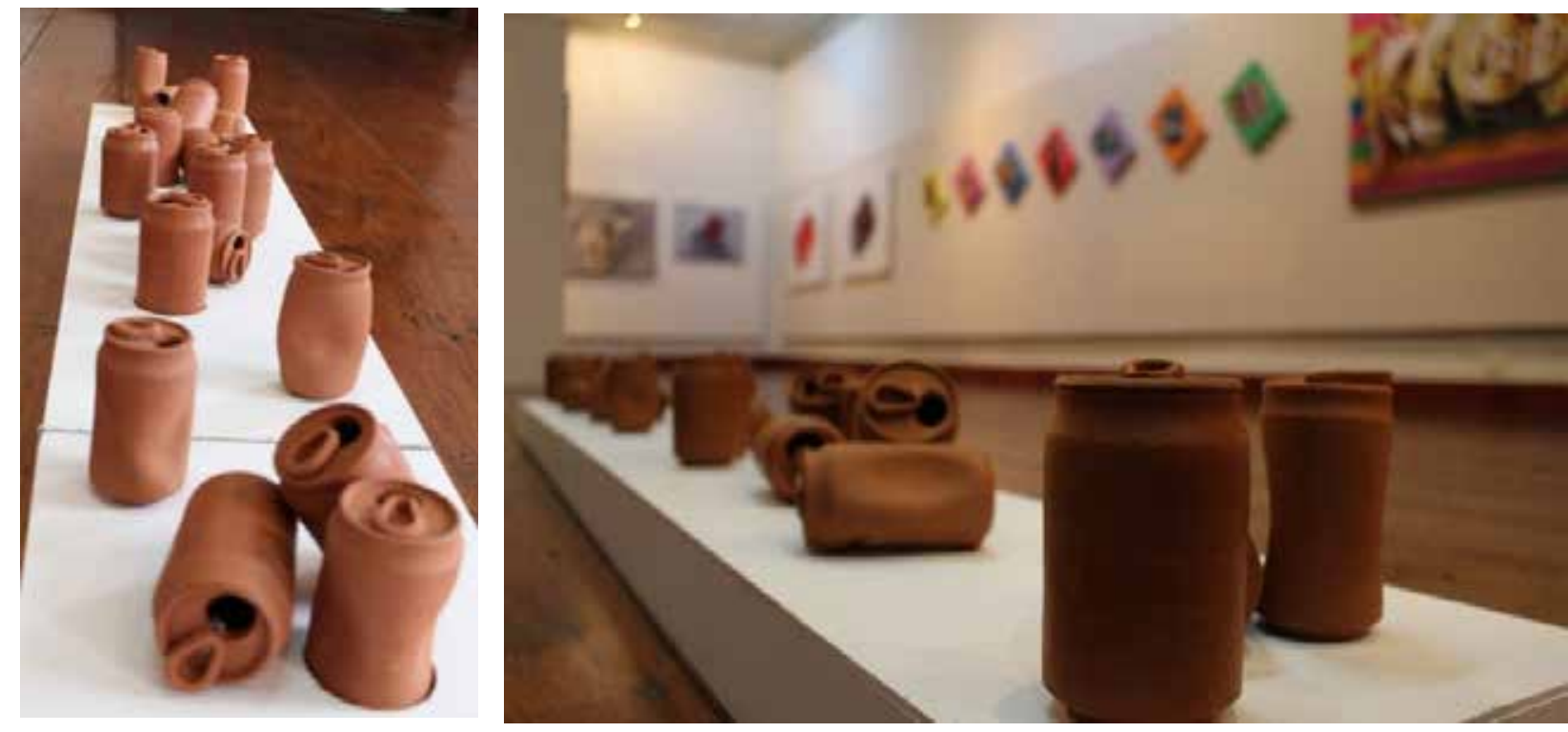

Figura 10 - Autora; Museu Regional de São João del Rei, Exposição "Entre Mares", obra "Engradado". Fonte: arquivo pessoal da autora. Fotografia:

Autora, 2017, 24 unidades.

Portanto, pela palavra-imagem múltiplo e suas acepções acolhidas, especialmente quanto à produção devota à gravura, tendo em vista àquele estar na sua própria modalidade existencial, procurei estabelecer um pensamento alçado no passado, remexendo no mesmo. E como citação de Adriana Varejão: "comentar sobre a tradição não significa estar estagnado nela. É preciso abrir sempre as janelas, movimentar o ar". (VAREJÃO apud TRIGO, 2010). Os artistas devem serem "como minhocas, que arejam a linguagem" - foi o que me propus, encerrando esta fala na cultura atual - arte contemporânea.

Destarte, com o discurso em voga, meus pensamentos se transformaram - então "sou outra". Isto é, digo que atingi aqueles "sopros que nos empurram para as beiradas da compreensão". (PELBART, 2013 apud PRECIOSA, 2019, p. 02). De igual sentido, espero ter deixado contribuições aos meus pares; ou ainda, ter atingido o mérito necessário a pesquisa segundo Rosane Preciosa (2019, p.1): não deixar que "a voz daquele que pensa e escreve encontra[r]-se ausente".

\section{NOTAS}

1. Ex-presidente da ANPAP - Associação Nacional de Pesquisadores em Artes Plásticas, biênio
(2009/2010) e banca examinadora: Prof.( Dra. Analice Dutra Pillar (FE/UFRGS, Editora-Chefe da Revista GEARTE) e Prof. Filósofo Dr. José Antônio Saja dos Santos (FFCH/UFBA).

2. Texto o qual o autor começou a escrever em 1936 e somente foi publicada em 1955.

3. Homens que integraram expedições artísticas e científicas nas Américas a partir de sua descoberta no século XVI. Suas produções estão ligadas ao ato de viajar; documentaram a fauna, a flora e os povos através de relatos, desenhos e pinturas. Espécimes naturais desconhecidos, animais estranhos e homens "primitivos" (às vezes "bons selvagens", outras, "selvagens-canibais"). Descrições que passaram a compor o imaginário europeu acerca do Novo Mundo.

4. A tinta chega ao papel permeando a matriz, isto é, atravessando-a (Cf. COSTELLA, 2006, p. 109).

5. Segundo Oiticica (1986, p. 22): “o que transforma [a matéria] em expressão é nada mais que um sopro: sopro interior, de plenitude cósmica. Fora disso não há obra. Basta um toque, nada mais."; sendo endossado pela expressão de Peter Pál Pelbart (2013), "Da Polinização em Filosofia", publicado no livro "O Avesso do Niilismo - Cartografias do Esgotamento". Neste, conforme apresenta 
Preciosa, "o filósofo alude aos textos de Deleuze e Guattari como sopros que nos fazem atravessar tribos, faunas, floras. Textos que trazem movimento, assim como nos traz os de Pelbart, e que nos empurram para as beiradas da compreensão". (PRECIOSA, 2019, p. 02).

6. $O$ referido documento legal foi estabelecido pelo Conselho Nacional do Meio Ambiente - CONAMA, através da Resolução n.) 275, de 25-04-2001 (Lei nacional, com regulamentação internacional).

7. Em um período em que o reconhecimento de um trabalho feminino era difícil, a artista aceita assinar o sobrenome do marido, "Walter Keane", casados de 1955 a 1965. Situação revertida via batalha judicial.

8. FARIA, Maria Isabel e PERICÃO, Maria da Graça. Dicionário do Livro: Da escrita ao livro electrónico. Coimbra: Edições Almedina, 2008.

9. DIDI-HUBERMANN, Georges. Formes généalogiques: L'empreinte comme matrice (Formas de genealogia: a impressão como uma matriz), Paris: Editions Minuit, 1993 c, p. 493 -502.

10. LADEIRA, Marcillene. Prática artística e pensamento teórico: a Pós-Graduação como campo de ação - um estudo reflexivo e alargador do conceito de "Rede". "18) Encontro Internacional de Arte, Ciência e Tecnologia", Universidade de Lisboa, Faculdade de Belas Artes - FBAUL, Portugal, 2019, pp. $1217-1228$.

\section{REFERÊNCIAS}

ALCANTARA, Marlon Cesar. História da Ciência, Filosofia e Arte na Holanda do Século XVII: construindo um módulo para o ensino dos instrumentos óticos. Dissertação (Mestrado). Programa de Pós-Graduação e Ensino de Ciências e Matemática do Centro Federal de Educação Tecnológica Celso Suco da Fonseca CEFET/RJ, 2011.

BALDUS, Herbert. Os carimbos dos Índios do Brasil. Coleção Nicolai, Revista do Museu Paulista, Nova Série, v. XIII. São Paulo, 1961/62.

BENJAMIN, Walter. A obra de arte na era de sua reprodutibilidade técnica. Porto Alegre, RS: L\&PM, 2020.
BENJAMIN, Walter. Obras escolhidas. Magia e Técnica, Arte e Política. São Paulo: Brasiliense, 1987.

CAMPOS, Joseane G. Políticas Públicas de Educação; Condições de Trabalho do Professor: os Reflexos do uso do Mimeógrafo no dia a dia dos professores e dos alunos da Rede Estadual Paulista - Ensino Fundamental I. Dissertação de Metrado, Educação, Universidade Cidade de São Paulo, 2009.

CAPRA, Fritjof. A teia da Vida: uma nova compreensão científica dos sistemas vivos. São Paulo: Cultrix, 2006.

COSTELlA, Antônio. Comunicação - do grito ao satélite. SP: Editora Mantiqueira, 2014.

COSTELLA, Antônio. Introdução à gravura e à sua história. São Paulo: Editora Mantiqueira, 2006.

DANTO, Arthur C. Crítica de arte após o fim da arte. Revista de Estética e Semiótica. Brasília, v. 3, n. 1, 2013, p. 82-98.

DIDI-HUBERMAN, Georges. 0 que vemos o que nos olha. São Paulo: Ed. 34, 1998.

GRANDES OLHOS (Big Eyes). Direção: Tim Burton. Drama Biográfico. EUA: The Weinstein Company, 2014 (1h46min). Lançamento no Brasil: jan. 2015.

LAUDANNA, Mayra. Maria Bonomi: da gravura à arte pública. São Paulo: Editora da Universidade de São Paulo, Imprensa Oficial do Estado de SP, 2007.

MARTINS FILHO, Carlos Botelho. Introdução ao conhecimento da gravura em metal. Rio de Janeiro, PUC, Solar Grandjean de Montigny, 1981 [1982].

MASON, Antony. História da Arte Ocidental: da pré-história ao século 21. SP: Rideel, 2009.

NOCERA, Lígia B. Tácitus: uma coleção particular de coisas inanimadas. 2011, $105 \mathrm{f}$. Dissertação (Mestrado). Programa de PósGraduação em Artes Visuais da Universidade Federal da Bahia. Salvador: BA, 2011.

OITICICA, Hélio. Aspiro ao Grande Labirinto. Rio de Janeiro: Rocco, 1986.

PAREYSON, Luigi. Estética: Teoria da Formatividade. Trad. Ephraim Ferreira Alves. Petrópolis: Vozes, 1993. 
PRECIADO, Paul B. Aprendendo com o vírus. Tradução Ana Luiza Braga e Damian Kraus. N1edições. "on-line", n 007, 2020. Disponível em: https://n-1edicoes.org/007. Acesso em: jun. 2020.

PRECIOSA, Rosane. Reparar nas coisas: de repente algo acontece e somos outro. Educação em Perspectiva, Viçosa/MG, v. 10, 2019, p. 1-7.

SALLES. Cecília Almeida. Redes de Criação: construção da obra de arte. SP: Horizonte, 2006.

SANTOS, Renata. A imagem gravada: a gravura no Rio de Janeiro entre 1808 e 1853. Rio de Janeiro: casa da Palavra, 2008.

$\mathrm{S} / \mathrm{A}$. Artista lançará versão brilho box de Andy Warhol em colaboração com museu do ícone da Pop Art. DASARTES, 2020. Disponível em: https://dasartes.com.br/de-arte-a-z/artistalancara-versao-brillo-box-de-andy-warhol-emcolaboracao-com-museu-do-icone-da-popart/. Acesso em: ago. 2020.

SOARES, Marta Isabel G. A Matriz: de Feuille de Vigne a Sem Título, Sobre Tela. (Dissertação de Mestrado, Pintura, Faculdade de Belas-Artes, Universidade de Lisboa, Portugal, 2011.

TÁVORA, Maria Luisa. Acrítica e a Gravura Artística - anos 50-60: entendimentos da experiência informal. Arte \& Ensaios, PPGAV/EBA/UFRJ, n.27, 2013, p.121-131.

TRIGO, Luciano. O corpo como metáfora: Adriana Varejão lança 'Entre carnes e mares' e fala sobre sua arte. Portal de notícias G1, Categoria Todas, 2010. Disponível em: http://g1. globo.com/platb/ maquinadeescrever/2010/05/04/820/. Acesso em: dez. 2014.

VASQUEZ, Rui Miguel Pinto. Múltiplos. (Trabalho de Síntese). Faculdade de Belas Artes, Universidade de Lisboa. Provas de aptidão pedagógica e capacidade científica. Portugal, 2000.

VENEROSO, Maria do Carmo de. O campo ampliado da gravura: continuidades, rupturas, cruzamentos e contaminações. ARJ, Brasil, vol.1/1, 2014, p.171-183.

\section{SOBRE A AUTORA}

Marcillene Ladeira é pesquisadora e professora do UNIPAC/Barbacena/MG. Mestra em "Processos Experimentais na Arte Contemporânea" pelo PPGAV/EBA/UFBA; especialista em Docência do Ensino Superior; licenciatura e bacharelado em Educação Artística com habilitação em Artes Plásticas pelo IAD/UFJF, com passagem inicial pela EBA/UFRJ; líder do grupo de pesquisa "VEIA" e membro do grupo "MAMETO CNPq". Tem experiência na área de Artes Visuais com galeria representante desde 2014. E-mail: marcilene.ladeira@gmail.com 